\title{
Remembered Light: Constants in the Fiction of John $\mathrm{M}^{\mathrm{c}} \mathrm{Gahern}$
}

\author{
Brian Hughes \\ University of Alicante
}

\begin{abstract}
Art is, after the failure of love, an attempt to create a world in which we might be able to live: maybe that world wouldn't last very long; it probably wouldn't last for ever; but it would be a world of the imagination over which we might rule ... We cannot live, we can only rule, although we have no reason and no right to rule; except our own instinctive need. Thus we rule in the illusory permanence of our false gods.
\end{abstract}

${\text { (John } \mathrm{M}^{\mathrm{c}} \text { Gahern) }}^{1}$

For a people long condemned to labour on the earth for their subsistence, the Irish are unusually apt to view the human body with contempt, in the light of a potential corpse rather than as a living source of pride and pleasure. To see in this the effect of a strict strain of Catholicism on a subdued northern people is to overlook both the Celtic reputation for wildness and the fact that some of the most thoroughgoing revilers of the flesh in the canon of world literature are Irish Protestants. The greatest of the mortifiers of the body and deniers of its privileges is, of course, the Anglican cleric Swift, the satirist who noticed that fundamentalist inspiration derived both logically and etymologically from wind issuing from the fundament, the inventor of the trade in Yahoo hide and the fascinated observer of the considerable difference flaying made to the back of a Dublin whore. In our own time, the grisly anatomies of the lapsed Calvinist Beckett make us wonder what grim pantomimes he might have conceived had his faith survived the onslaughts of the world outside his pious mother's home, or had he elected, more simply, to live in Ireland rather than in France. In the work of some contemporary Anglo-Irish writers, to use that term in its classic sense of Irish Protestants, we meet the same unmistakable stench of putrefaction, and the same mocking, macabre wit. I am thinking 
of the novelist John Banville and the poet Derek Mahon, though there is a somewhat heavier version of it in the novels of Aidan Higgins.

On the Catholic side, Joyce's early work is often said to examine the crippling effect of sexual guilt on the sensitive individual, but in view of the ambivalence with which the body is treated in Ulysses and Finnegans Wake, Joyce might as easily be said to indulge the morbidity as to disdain it. Flann O'Brien's textual buffoonery and verbal legerdemain have understandably received more critical attention than has his eye for the physically gruesome, but his characters when viewed from this perspective are not a pretty sight; their unhealthy pallour, uncouth clothing, unhygienic habits and unwholesome diet are, we then realise, an important part of their author's uncomfortable comedy, which partly depends on the elaborate avoidance of human contact. It may have been this, as well as the uncanny stillness and emptiness of the landscapes of his fiction, that Lorna Sage was noticing when she shrewdly pointed out that O'Brien's world was lifeless. ${ }^{2}$

John $\mathrm{M}^{\mathrm{c}} \mathrm{Gahern}$ therefore had a lengthy tradition to draw on for his intense and desolate stories of the competing tyrannies of mind and body; but the originality of his writing, though it is a strange thing to have to say, is that it succeeds because it is utterly devoid of humour. Beckett haunts and harrows, but I have never understood readers who claim to be afflicted by his work: there is no more bracing, no more astringent stylist in print, and very few less given to self-pity; and his mordant wit is never more effective than when he has lulled us into a false mood of plangency and comfortable lugubriousness. It is not so with $\mathrm{M}^{\mathrm{c}} \mathrm{Gahern}$; clinging fiercely to the representative modes of realism, he employs what in one of his stories ${ }^{3}$ he calls "careful neutrality" to present the unbearable heaviness of being, the unequal battle between the world and the flesh, the isolation of the individual and the misery of mortality. All his novels deal more or less explicitly with these large metaphysical questions and it is as well to be clear from the outset about the awkwardness this involves the reader in. Ideas unfashionably intrude on $\mathbf{M}^{\mathrm{c}} \mathrm{Gahern}$ 's fiction, ideas which are themselves stubbornly unfashionable, and there is neither wit available to counterpoint them, nor irony to subvert them, nor a countervailing subtext to deconstruct or circumvent them. His people suffer irremediably; their lives are doomed or stricken; their circumstances harsh and loveless. With half-abashed solemnity and a shambling kind of dignity, his characters fumble towards the formulation of unanswerable questions for which Dostoevsky is a more obvious model and mentor than either Joyce or Beckett: "Her life was either under the unimaginable God or the equally unimaginable nothing; but in that reality it was under no lesser thing."4

So thinks Elizabeth Reegan, a former nurse in England, now the second wife of an Irish policeman, living with him and his children by the first marriage in the guards' barracks in a godforsaken village in Connaught. "Living" is one way of putting it: to be accurate, Elizabeth is dying, slowly, and painfully, and unmercifully young, of cancer, a disease for whose symbolic awfulness $\mathbf{M}^{\mathrm{c}}$ Gahern has the greatest respect. It also figures prominently in The Leavetaking (where long ago, but unforgettably, it claimed the life of the protagonist's mother) and in The Pornographer (where it is stubbornly but uselessly resisted, with the help of brandy, by the protagonists'aunt). In The Dark, the early death of the boy's mother is not explained, but it forms part of the same picture, as does that of Moran's first wife in Amongst Women. 
Thus, the first world delineated in all the novels is one of strained or maimed relationships in households dominated by a taciturn, harassed and often violent father; the children grow up motherless, but commonly with the recollection of a mother's tenderness and the haunting memory of the beauty of her face. The darkness of absence, the melancholy of stilted conversations, the father's embarrassing silence and even more embarrassing love, the drudgery of the present, the bleakness of the future and the fear and mystery of death: such are the experiences of childhood in $\mathbf{M}^{\mathrm{c}} \mathrm{Gahern's} \mathrm{comfortless} \mathrm{world.}$ Elizabeth, like Rose in the latest novel, Amongst Women, enters the household as the strange woman, the substitute mother, which is a hard enough role to play without the added difficulties of dealing with Reegan's brooding, dissatisfied and intensely inward character. As she learns to come to terms with the fact of her impending death, she goes over in her mind the passionate but doomed affair she had had years before in England with Halliday, a cynical and disillusioned doctor whose death in a car crash was probably suicide, given his self-destructive nature. Her musings on the nature of life and love and death are made no easier for her by the fact that Halliday had wilfully destroyed their relationship before he put an end to his own life. The children, for their part, have experienced the incomprehensible loss of their own mother and the tense and ferociously protective love of their relentless father; they must now face the wasting illness of their foster mother, whose reasonable love they have no sooner learned to trust than it is snatched from them.

In The Dark, where there is no mother and hardly the memory of one, the children live in fear of their despotic father, whose fanatical devotion to the idea of family unity takes the alternate forms of beatings, cajolery, whingeing, maudlin self-pity and feeble, awkward pride. Early bereavement and the need for self-defence no less than the cramped living conditions of their farm have forced them into an uneasy intimacy that shows more clannish solidarity than real brotherly love. The young protagonist takes refuge in the dark of his own mind, in masturbatory fantasies and in the equally improbable dream that he will one day keep a promise exacted by his mother to become a priest. The suffocating closeness of unwanted intimacy that is such a hallmark of $M^{\mathrm{c}}$ Gahern's fiction first appears in this novel and is to return in The Pornographer and Amongst Women.

The unseemly intrusions of coarse reality on the pure of heart is an unlikely subject for a modern novelist, but it is $\mathbf{M}^{\mathrm{c}}$ Gahern's. All these dead and dying mothers and wives, all these austere and passionately driven fathers with their explosions of rage and their fanatical love, create a stifling environment for their sons and daughters to grow up in, but they also plant in them the seed of the ideal for which they yearn for ever after. Growth in $M^{\mathrm{c}}$ Gahern's novels is a painful and humiliating process; violent rebellion (The Dark), cowed submission (The Barracks, Amongst Women) or exile (sooner or later in all the novels) are the natural responses. Perhaps it is worth noticing that pragmatic cynicism, which I would surmise is the commonest defence against these circumstances in real life, is never made the central issue: $\mathbf{M}^{\mathrm{c}} \mathrm{Gahern}$, as we shall see, is not interested in people who duck issues. Mahoney and his nameless son in The Dark finally work out a tentative kind of truce, the father agreeing with the boy's decision to give up his hard-won place at the University and seek some alternative way of life. This may be a calculated move by $\mathbf{M}^{\mathrm{c}}$ Gahern to reverse the Joycean ending of exile, but it is also psychologically motivated 
in the boy's grudging admiration for his father ("No matter what else, he had at least the beauty of energy"; "You are marvellous, my father" ${ }^{\text {"); }}$, and it takes on more resonant meaning from the paradox finally expressed by the boy (now a young man) near the end of the novel:

You could go to the E. S. B. If it was no use you could leave again, and it didn't matter, you could begin again and again all your life, nobody's life was more than a direction.

You were walking through the rain of Galway with your father and you could laugh purely, without bitterness, for the first time, and it was a kind of happiness, at its heart the terror of an unclear recognition of the reality that set you free, touching you with as much foreboding as the sodden leaves falling in this day, or any cliche.

In Amongst Women, the quitters, Luke and Michael, are allowed to drift out of the central focus when they choose to make their lives in England, thus shirking the conflict with their father's values and the whole matter of Ireland. The novel stays resolutely with the tight circle the dying Moran's wife and daughters form around the old guerrilla fighter: it is the women who give the book its title and they who are to be the inheritors, a point we shall return to. Clearly $\mathrm{M}^{\mathrm{c}} \mathrm{G}$ ahern is interested not in those who protect themselves against life, but in those who face up to it or succumb to it. As Roger Garfitt put it, $\mathbf{M}^{\mathrm{c}}$ Gahern's work shares with Francis Stuart's the view that "experience is lived, as it were, within sight of annihilation, and what values it can retain, it draws from this perspective." 6

The almost impersonal terms Garfitt uses here are a response to the elemental (not the elementary) nature of $\mathbf{M}^{\mathrm{c}} \mathrm{Gahern's} \mathrm{premises.} \mathrm{Landscape,} \mathrm{weather,} \mathrm{darkness} \mathrm{and} \mathrm{the} \mathrm{quality}$ of the light are burned into the consciousness and the memory of the characters, and gain first lyrical and then symbolic intensity in a way that partly recalls Beckett's use of these patterns of imagery in the Trilogy or From an Abandoned Work. They have both the clarity and particularity of precise observation and the universalising function of the poetic image; together they speak of the uniqueness of experience and of the paradox of its simultaneous immediacy and remoteness from the mind hungrily and vainly scanning it for signs of comprehensibility.

A similar general effect is produced by the casualness with which $\mathbf{M}^{\mathrm{c}} \mathrm{Gahern}$ names or refrains from naming his protagonists. His distinct preference is always for the personal pronouns over any proper noun: Elizabeth is only "Elizabeth" when "she" would not be clear enough, and she is sometimes even "Mrs Reegan" when $\mathrm{M}^{\mathrm{c}} \mathrm{Gahern}$ wishes to be exceptionally literal about his "careful neutrality." The boy protagonist of The Dark has no name at all, the narrative weaving together "I," "he" and "you" in a thorough technical overhaul of him inside and out. His father is sometimes "Mahoney" but more often "he," even, with realistic bitterness, when he is being discussed in his absence by his resentful children. The richly Irish vocative "my father," which I quoted a moment ago, beautifully catches the boy's tone of uneasy intimacy, a mixture of reverence, love and fear. The pornographer has no name either, and though the schoolteacher of The Leavetaking is called Moran, and we learn in an offhand way that his Christian name is Patrick, $\mathbf{M}^{\mathrm{c}}$ Gahern allows him to tell his own story in the most impersonal of first-person narratives. Finally, Moran is once again the name of the protagonist of the latest novel, and 
though the conventions of naming are at their most ordinary in this book, the general tendency of $\mathbf{M}^{\mathrm{c}} \mathrm{Gahern's}$ fiction, novels and stories alike, is to dispense with the compact sense of identity names are assumed to give and so to make his stories that much more universal, though as I have suggested they are anchored in the vivid particularities of rural Ireland - the Midlands and Connaught, to be exact.

A similarly departicularising effect, though it is anything but an estranging or defamiliarising process, results from $\mathbf{M}^{\mathrm{c}} \mathrm{Gahern}$ 's habit of repeating small details, situations or formulae from one novel to another. These repetitions range from family customs (e.g. the saying of the family rosary, each member taking a decade, all kneeling on folded newspapers, and the father opening the ceremony with the formula "Thou, O Lord, wilt open my lips," which is common to The Barracks, The Dark and Amongst Women, even down to the detail of the worn leather purse in which Reegan and Moran keep their beads) to textual echoes ("the road away becomes the road back," which sounds very like Heraclitus but is $M^{c}$ Gahern's own, and occurs in both The Barracks [p. 158] and The Pornographer [p. 203]). There is also the car seat that has been converted into a kind of parental fireside throne in both The Dark and Amongst Women. The Barracks and The Leavetaking have similarly harsh father figures who are guards or Irish policemen; the thump of their boots on the concrete floor of the barracks when they arrive home for their meals is often, in both novels, matched by a rise in the nervous tension of the household. Moran in Amongst Women is like an older version of Mahoney in The Dark, while Moran (the schoolteacher in The Leavetaking) and the pornographer bear an uncanny resemblance to one another. Elizabeth Reegan's profession of nursing is mirrored by the dark-haired beauty who captivates the protagonist of The Pornographer with the efficient and humane care she takes of his aunt as much as by her good looks, ready laughter and generous sensuality. And the quiet shrewdness with which Elizabeth soothes the temper of her husband looks forward to the domestic tact and resourcefulness of Rose, Moran's second wife in Amongst Women.

Readers are not surprised to learn that the characters and the incidents related in the novels bear a close resemblance to members of $\mathrm{M}^{\mathrm{c}}$ Gahern's own family and their personal histories, including the novelist's own. This seems to be most closely mirrored in the story of the schoolteacher in The Leavetaking, who loses his job because he marries an American divorcee in a registry office, thus setting a bad example for Irish Catholic youth. Nevertheless, with the single exception of this novel, it makes no difference at all to our estimate of $\mathrm{M}^{\mathrm{c}} \mathrm{Gahern's}$ originality to know, or to suspect, that he is telling us of things he knows because they are his life; what matters is that, in the way that they are told, they transcend that singularity. In his defiant realism, $\mathbf{M}^{\mathrm{c}} \mathrm{Gahern}$ beats an old road back to the essentials for which no label serves, as Beckett had done over a quarter of a century earlier.

Beckett once wrote, in a fine moment of scorn, ${ }^{7}$ that habit is the ballast that chains the dog to his vomit. $\mathbf{M}^{\mathrm{c}} \mathrm{Gahern's} \mathrm{rhetoric} \mathrm{is} \mathrm{more} \mathrm{lyrical,} \mathrm{but} \mathrm{it} \mathrm{works} \mathrm{as} \mathrm{remorselessly} \mathrm{at}$ stripping away the comfortable cocoons we spin for ourselves in our intellectual, metaphysical and spiritual torpor. The Ireland he depicts is a living anachronism, but this is appropriate to his focus and relieves him of the clutter that so encumbers the work of writers from the so-called privileged so-called centres of the contemporary world. He is 
rid by his circumstances of all the rigmarole of triteness and banality and of all the shoddy goods with which which an obsolescent modernity has decked out its junk bazaar. With the freedom of Heraclitus he is able to concentrate on the essentials of experience, and to record the beat of consciousness and the insoluble mystery of time. "Coming into onself" is how his characters experience this barbarous knowledge (and 'Coming Into His Kingdom' is the wry title of a short story on precisely this theme) ${ }^{8}$ Here is Elizabeth Reegan's mind struggling to formulate the idea:

the whole world beginning again as it always has to do when a single human being discovers his or her uniqueness, everything becoming strange and vital and wondrous in this the only moment of real innocence, when after having slept forever in the habits of other lives, suddenly, one morning, the first morning of the world, she had woken up to herself. (The Barracks, p. 87)

If the dying Elizabeth is both comforted and appalled by these rushes of mystical insight, it is because the sense of her own uniqueness thus vouchsafed has a devastating corollary: the unrepeatable particulars of her memories and her experiences isolate her once and for all from every other human creature. The leap of sympathy that seems to carry the mind beyond itself and its occasions in fact brings it up against the blank wall of its inescapable separateness. To know that we are all in the same prison of the timebound self is not much of a consolation, as is made plain in the fine scene, presented entirely through Elizabeth's consciousness, in which the frightened women in the cancer ward receive their weekly visitors:

She and they were involved together: they jigacted with millions of others across a screen's moment, passionately involved in their little selves and actions, each of them in their own mind the whole world and everything; all of them tragic figures in their death, there was no joke there byjesus, the whole world falling when they fell. It was so fantastic and so miraculous that it could go on in spite of having no known purpose, blind passion carrying it forward in spite of everything ... She was no different, that was the terrible thing, she was no more than a fragment of the same squalid generality. (Ibid., pp. 136-7)

Since this is the predominant outlook of $\mathbf{M}^{\mathrm{c}} \mathrm{Gahern}$ 's people, it is natural that they should be intent observers of the world they were born to lose. Brooding selfconsciousness and a rich responsiveness to the beauty of the workaday world are habitual with them, as is the Beckettian sense that everything is immersed in the corrosive, colourless fluid of time, that the world is literally disappearing as they watch, eaten away by this cancer that afflicts subject and object of thinking alike. Passage after passage in $\mathbf{M}^{\mathrm{c}}$ Gahern's work returns to this central idea and I hope I will be forgiven if I illustrate this by quoting one short instance from each of the novels to set beside the fragment from Elizabeth's rêverie: 
I watch a gul!'s shadow float among feet on the concrete as I walk in a day of my life with a bell, its brass tongue in my hand, and think after all that the first constant was water. (Moran in the first sentence of The Leavetaking, p. 9)

Through the green gate with the corn above it facing the Leitrim road for the last time. Down the town; the shops, Flynn's and Low's, the town clock, past the barracks, and over the stone bridge across the Shannon, Willie Winter's garage and the galvanized paling about the football pitch of the Streets' League.

They were gone, the places in their days, probably able to see them again but never this way, coming from the day of the school. Part of my life had passed in them, it was over, to name them was to name the dead life as much as them, frozen in the mystery of love. (The boy in The Dark, p. 145)

To find we had to lose: the road away became the road back. And what company we met with on the road, we who no longer sought company, at what fires and walls did we sit. Our wits were sharpened. All the time we had to change our ways. We listened to everything with attention, to others singing of their failures and their luck, for we now had our road. All, all were travelling. Nobody would arrive. The adventure would never be over when we were over. It would go on and on, even as it had gone on before it was passed on to us. (The Pornographer, p. 203)

By the time Maggie had to go back to London they had never felt closer in warmth and happiness. The closeness was as strong as the pull of their own lives; they lost the pain of individuality within its protection. In London or Dublin the girls would look back to the house for healing. The remembered light on the empty hayfields would grow magical, the green shade of the beeches would give out a delicious coolness as they tasted again the sardines between slices of bread: when they were away the house would become the summer light and shade above their whole lives. (Amongst Women, p. 85, on Moran's daughters)

All of these passages show the circularity imposed on consciousness and experience by the persistence of memory. It is through memory that the characters re-collect the scattered fragments of their existence, just as it is partly through memory that $\mathbf{M}^{\mathrm{c}} \mathrm{Gahern}$ himself has brought their circumstances to coherence. The Muses were the daughters of Memory, and the intense lyricism as well as the searing nostalgia of the passages quoted show the tendency of $\mathrm{M}^{\mathrm{c}} \mathrm{Gahern}$ 's prose to slip into the rhythms and images of poetry when he penetrates beyond a certain depth into the consciousness of his creatures. It is this technique and this sort of passage Jonathan Raban is referring to when he writes that $\mathrm{M}^{\mathrm{c}}$ Gahern's genius is for "mediating between the deep currents of feeling which belong to myth and history and the exact texture of the moment."

However, this intensity has its risks. There is first of all the old problem of tone: pushed beyond a certain limit, which it is impossible to fix until it has been violated, sincerity of utterance becomes portentousness, authenticity becomes pomposity, the sublime proverbially becomes the ridiculous. Eschewing irony, or incapable of it, as we have said, $\mathbf{M}^{\mathrm{c}}$ Gahern aims at a taut and resonant prose and asks it to carry an unusual 
weight of wrought feeling and nervous tension. As some of the passages quoted show, he relies on structurally simple sentences with strongly regular rhythms, and he risks occasional slight oddities of punctuation to provide small emphases of cadence and emotion. But things can go embarrassingly wrong with a prose style which has made no provision for containing or excluding the ludicrous. Here is an example, from Elizabeth's speculations, of how the style can come unstuck: "a total love was the only way she had of approaching towards the frightful fulfilment of being resonant with her situation" (p. 152). Media hacks talk and write this way, as do film producers, directors and interviewers; and seminars in sociology and psychology are awash with cant of this kind. But the limp jargon of the fuzzy social sciences will decidedly not do from the lips of a terminal cancer patient supposed to be struggling with the great truths of life and death.

To be fair, $\mathbf{M}^{\mathrm{c}}$ Gahern was aware of a tendency in his writing to what he calls "reportage," which brings us to the second risk to which his ardent style is peculiarly exposed, viz. the triteness of received ideas, the subsumption of the grappling consciousness into an external, intellectualising framework of abstract concepts. $\mathrm{M}^{\mathrm{c}} \mathrm{Gahern}$ partly rewrote the second half of The Leavetaking while he was helping his French translator with the text, and when the book was reissued in English, he added a brief comment on this "luck of a second chance." Part of his confession ran as follows:

The crudity I was attempting to portray, the irredeemable imprisonment of the beloved in reportage, had itself become blatant. I had been too close to the "Idea," and the work lacked that distance, that inner formality or calm, that all writing, no matter what it is attempting, must possess. ${ }^{10}$

It seems that the will has been taken for the deed, at least by the commentators who have chosen to notice the matter; but I do not see that the rewriting has achieved all that much. $\mathbf{M}^{\mathrm{c}}$ Gahern's problem in the two middle novels, The Leavetaking and The Pornographer, is precisely the one he identifies: it is getting too close to abstraction, to a set of ideas which are irrelevant to the world he has half imagined and half remembered. We find this "Idea," with the capital "I" the novelist gives it, staring at us even from some passages of the excellent first half of The Leavetaking. A passage, for example, like this:

O the opposite of my love in the room in Howth, the love of the Other that with constant difficulty extends its care to all the things about her so that they shine in their own loveliness back to her as the circle closes in the calmness of the completed self, the love that I'll be fired from this school for at eight. (p. 22)

What we have here is the notation not of the novelist but of the analyst, and a prose which, for want of a better term, we might call technocratic. It is blatant "reportage," right down to the spelling of "Other" with a capital " $O$ " which declares the allegiance of the passage with existentialist philosophy and Lacanian psychology. The problem is not that the novel grapples with ideas; as we have seen, that is a major premise of $\mathbf{M}^{\mathrm{c}}$ Gahern's fiction, and one source of its strength and originality. It is the second-hand nature of some of these 
ideas, the fact that they have not been translated out of their philosophic or text-book originals and welded to the characters' development, that disturbs us - or disturbs me here. Moreover, and more bluntly, the second half of The Leavetaking continues to fail because the London setting and the London life and speech it attempts to impose on the narrative are insubstantial, as are the personality and family background of the American divorcee who causes the rift between Moran and the school authorities. Her story, and even her speech, are written from hearsay or from inadequate observation. One need only compare them with the Canadian scenes of such Brian Moore novels as The Luck of Ginger Coffey or The Mangan Inheritance to see how weak $\mathrm{M}^{\mathrm{c}} \mathrm{Gahern}$ 's grasp is. Moore's Montreal is a real place; $\mathbf{M}^{c}$ Gahern's London might be anywhere, and his notional America is nowhere at all.

Jonathan Raban, who admires the novel immensely, is very acute about the nature of the problem:

As long as The Leavetaking stays in Ireland, it reads like a masterpiece. Its landscapes, set in Leitrim and Dublin, build up powerfully, soaked in the grey drizzle of Catholicism and its priesthood. The young man and the boy he once was grow from this dark country mutinously and inevitably ... But, quite unexpectedly, the novel suddenly goes adrift when it moves to London and the love affair with the American girl... We have been suddenly ejected from that world where everything is known, and needs only to be hinted at to come alive, into a place, a country, a state of mind, where everything needs to be explained. And $\mathrm{M}^{\mathrm{c}} \mathrm{Gahern}$, so brilliant on the familiar, turns out to be surprisingly clumsy when it comes to dealing with strangers. ${ }^{11}$

It is therefore a real relief, to the reader as well as to Moran's employers, when his sabbatical ends and he returns to Ireland and to the house-hunting episode in Howth. The difference is apparent immediately, the troublesome interlanguage disappears, and the brief encounter with the old vegetable hawker is one of the finest things in the book. No doubt $M^{\mathrm{c}}$ Gahern's dilemma was that he was really writing his own story and knew that that was how it had happened; but even so, he had forgotten that it is not the external issue of what happens next that really matters in fiction, but the patterns of living and feeling which give mere event its ground and its coherence. Not for nothing did Joyce end A Portrait with Stephen's diary entry announcing his departure; Paris is irrelevant to what the novel has to show. Likewise Stephen is brought back to Dublin for his mother's funeral and Irish Literature's day of reckoning in Ulysses, and it is "dear dirty Dublin" that informs the multicultural, multilingual highjinks of Finnegans Wake, which would be incoherent - and would have been inconceivable - on any other terms. $\mathbf{M}^{\mathrm{c}}$ Gahern, to give him his due, seems to feel the truth of this, and he makes Moran say of the "fanatical peasant," his headmaster, in the course of their last interview, "I loved his narrow passion, faithful to the person that he was, so alien to my uncertainty." Yes, indeed.

It is to this fanaticism and to $\mathbf{M}^{c}$ Gahern's superb command of the mental life of provincial Ireland that we shall now turn. Some earlier critics of the work rather resented the narrowness of Irish life and the dearth of spirit they took $\mathbf{M}^{\mathrm{c}} \mathrm{Gahern}$ to be bemoaning in his first two novels, and protested about the bleak view of existence the books appeared 
to them to propound. "The Dark Is Not Light Enough" seemed to one commentator to be an appropriate title for an essay on $\mathbf{M}^{\mathrm{c}}$ Gahern's novels; ${ }^{12}$ and another, in tackling The Barracks, remarked on the novel's "withering environment" and its "vision of despair." ${ }^{13}$ As recently as 1981, another author was still confidently writing of $M^{c}$ Gahern's fourth novel, The Pornographer, as a book presenting life with "bleak pessimism and nihilist cynicism."14

The simplest way of answering judgements of this kind is to remind ourselves that since works of literature are not about hope or despair or optimism or pessimism, but rather are constructions framing imaginable worlds in which such questions quite naturally arise or not, as the case may be, the statements are either meaningless or incomplete. King Lear, we could say, is a play that is full of coherently presented horror and despair and is therefore a rich and challenging response to a view of life more commonly upheld in public than in private. Waiting for Godot could likewise be described as a play which makes deliberate and painful and highly original fun out of the very idea of despair, since what can hope mean? A less successful and altogether more dubious ploy is to take the criticism at face value, and argue that what looks black is really white if examined from a suitable angle. Such argument is more likely to lead to distortion than to clarification, however well-intentioned, and this is, I believe, what happens to Suzanne Fournier's alternative reading of The Pornographer. ${ }^{15}$ The essay presents the pornographer as a man restored to emotional health by the redemptive power of love, the inevitable consequence being that $\mathbf{M}^{\mathrm{c}} \mathrm{Gahern}$ is cast in the role of a species of soft-hearted Dominican. These novels present experience as something sterner and far less pliant than Fournier's view allows; with truths universally acknowledged and sentimental piety they have little or nothing to do. Garfitt puts the matter more precisely and very much more subtly when he writes that $\mathbf{M}^{\mathrm{c}}$ Gahern's "deliberately bare style" is "a means of allowing experience to have the last word." What this means is that " $\mathrm{M}^{\mathrm{c}}$ Gahern's clarity of focus comes from the admission of inner emptiness, so that what begins as something very like nihilism ends as an outgoing, inquiring impulse." 16

$\mathbf{M}^{\mathrm{c}}$ Gahern's Ireland, as we said, is principally confined to the townlands of Connaught. We should add now that, historically, it is the country that emerged from Partition and the civil war, where most of those who had no land of their own to farm had to submit to the humdrum routine of civil service jobs, like Reegan's as a guard. The choice was thus between backbreaking toil on demanding land in a harsh climate, and the soul-destroying tedium of endless patrols, inspection of tillage returns and intervention in dance-hall punch-ups. Both constant heavy labour and grinding monotony call for special qualities of relentlessness, long-suffering, self-denial and dogged persistence. These are precisely the qualities we find in Reegan, in Elizabeth (women work, grind and sweat as much as men in $\mathbf{M}^{\mathrm{c}}$ Gahern's world), in Mahoney and his son, and in Moran, who faces into his hours of schoolteaching with the same combination of distaste and savage determination as Mahoney and Reegan display in their orgies of turf-cutting and potato-digging. But perhaps it is the second Moran, in Amongst Women, in whom we see this work ethic at its most intense. It will be seen that The Pornographer is the odd one out; not only does it not fit into the scheme we have just outlined, but it is, to me at least, a less satisfactory piece of writing altogether. Is it a jeu d'esprit, a wry self-portrait, an angry rejoinder by 
$\mathrm{M}^{\mathrm{c}}$ Gahern to the jibes of his detractors and the fools who banned The Dark as pornographic, or an attempt to come to terms with an ambiguous part of himself? In any case, it is a book requiring particular analysis which we cannot embark on here. ${ }^{17}$ Perhaps it was something its author had to work out of his system so that he could return in Amongst Women (his first novel in ten years) to his abiding theme of endurance.

The autocratic peasant Moran, with his patriarchal tyranny, his impenetrable selfsufficiency and the ferocious, tongue-tied tenderness that scalds the hearts of his daughters, is clearly a reversion to type and confirms our impression that The Dark refuses the Joycean ending because it refuses to choose between father and son. In the latest novel, the body's dream of release - never much more, in any case, than a few poor paroxysmic fits - receives short shrift. Young Michael Moran has to tread the same furtive, fumbling road of love that leads his predecessors to awareness of what The Dark calls "the shame of intimacy," while his brother Luke has long since opted for retreat to England and the safety of a frankly uninteresting anonymity. Both young men are placed, in the end, firmly outside the circle the three girls form about their father. Two key scenes, which are among the best in the novel, emphasise this, and in both the image of the circle is dominant. In the haymaking episode (pp. 83-85) Moran relentlessly drives the tractor round and round the hayfield, while his daughters work themselves into the dark release of stupor and oblivion under the blazing August sun, with Michael skulking and malingering on the fringes. Later there is the scene at the dance when the sisters form themselves into a "closed, angry circle" (p. 102) and a "tight knot of indignation" (p. 103) to show their disapproval of Michael's liaison with the sexy Nell Morahan. Nell is a former local skivvy, now unsurprisingly a waitress in America, who is home on holiday with money to burn, and she takes this opportunity of showing the handsome, feckless young ne'er-do-well a thing or two in the back of the car.

Nevertheless, I do not mean to suggest that $\mathrm{M}^{\mathrm{c}}$ Gahern's treatment of sex is puritanical, or that sex is unimportant in his fiction. Indeed, it is central enough in The Dark (where, apart from the boy's fantasies, it appears in the latent homosexuality of the father and his brother the priest) to have got that book banned in the old censorship days in Ireland, and it is, of course, the explicit theme of The Pornographer, though like everything else in that novel it receives ambiguous treatment. But desire, the body's will, is as much part of the darkness as is the mind's will we call consciousness, and it follows a similarly cyclical pattern in the novels: yearning, relief, bafflement and the return to isolation. Indeed, $M^{c}$ Gahern's straightforward and objective handling of the sex scenes in his novels exhibits the same sort of fascination with the rhythms of moving bodies as is evident in the frequent descriptions of human labour. Behind the exertions of his lovers and his toilers lies the same frenzied blindness of appetite and the same half-conscious muscular control. Both activities are presented as a driving of the self which is also, blessedly, an absence from the self, a sealing-off of the conscious will from its attendant circumstances. These are moments of holiday from the iron discipline of time, and from them the characters return not exactly refreshed, but spent into the pleasurable numbness of exhaustion, stupefied into acquiescence.

Physical love is, then, like work, an activity of the unconscious will that provides a respite from the rigours of self-scrutiny. It is of a piece with the inwardness of their lives, 
the awkwardness of their social manner, the customary nature of their spoken exchanges. Labour and love-making fit into the curiously formulaic patterns of the dialogues and of the routines of day-to-day living. These frenzied spurts take the edge off the characters' intent solitude, their brooding dissatisfaction, their hunger for the absolute and their fundamental contempt for themselves and the way things are. I do not see in this the salvation-through-love Suzanne Fournier seems to imply: there is neither a Christian spirit of surrender nor a Lawrentian ethic of fulfilment available in these novels. But neither does $\mathrm{M}^{\mathrm{c}} \mathrm{Gahern}$ 's presentation of sexuality have the sardonic ring of the love encounters in Beckett, from the witty application of Aristotle in More Pricks Than Kicks ("They had not been very long on the top [of the hill] before [Belacqua] began to feel a very sad animal indeed") to the travesties of copulation in the later novels, Molloy and Malone Dies in particular. Beckett's disconcerting comedy in these passages is directed, as it so often is, at the lazy habits of sentimental cliché with which we are so commonly inclined to prop up our lives, whereas $\mathbf{M}^{\mathrm{c}}$ Gahern's people are more straightforwardly plagued by the exasperating difficulty of things and the long history of human disappointment. They are all the more willing to take comfort and pleasure where they can find them.

Moran's shroud awaits him almost from the beginning of Amongst Women, and it is typical of $M^{\mathrm{c}}$ Gahern's harsh symbolism and of his sardonic presentation that the brown Franciscan habit in which the old guerrilla fighter is to be buried should be hidden by Rose in their bedroom among her underwear. Yet the doomed Moran grows in stature as his life draws to a close, almost as if it were a law of this fictional world, as it seems to be of Beckett's, that characters become more human the fainter their chances of survival. In any case, I think it is fair to say that the reader's half-reluctant admiration for the old peasant's indomitable will and his lifelong ethic of dogged self-reliance finds support in his daughters' increasing closeness to him and their gradual assimilation of his qualities and outlook. By the end, they are bent on saving him, as most of $\mathrm{M}^{\mathrm{c}} \mathrm{Gahern}$ 's characters sooner or later dream of saving themselves, by the sheer power of their will. The futility of this project is, of course, partly the measure of its courage and humanity, and the continuity which always marks the endings of these novels is here clearly set out in one of the closing sentences, which ends: "and now, as they left him under the yew, it was as if each of them in their different ways had become Daddy." (This, by the way, is an indication of how the slightly misleading title of the novel is to be understood: not as a programmatic statement of the old warrior's harshness being gradually tamed by the softening influence of his womenfolk, but on the contrary, as a suggestion of the irresistible pull exerted from the centre of the tight circle the women come to form around the dying Moran. I am less sure about the possible religions associations of phrase. If we are meant to recall the formula in the "Hail Mary," I would surmise that the reference is partly sardonic, especially in the light of Moran silencing of the rosary on his death bed.) Moran's last few solitary walks around the farm that has come to circumscribe his world stress the persistence of his dominion and the circular nature of experience, naturally enough; but $\mathbf{M}^{\mathrm{c}}$ Gahern also uses these occasions to give point to Moran's experience of how hard it is to die, for "he had never realized when he was in the midst of confident life what an amazing glory he was part of." Many readers will find in this, and in similar statements which recur in the 
novels, evidence for a conviction that the stories, for all their pain and harshness, are not finally comfortless.

Lust and labour, then, rather than the milder virtues of love and work; the ferocious, driven intensity of lives lived under the threat of deprivation or extinction; the travail of passion and possession; and despite it all, the difficulty of final leavetaking - these are the constants of a fiction which, though it is certainly narrow in the range of the experiences it is prepared to take account of, is strikingly clear-sighted about the grounds of that narrowness and the possibilities for reasonable affirmation which, a little like Hardy's, it yet contrives to provide. $\mathbf{M}^{\mathrm{c}}$ Gahern is not an accomodating novelist; there is no room in his fiction for blandishment or blarney, and if, as I have said, he eschews irony, he is also curiously reluctant to avail himself of the charm and seductiveness so often to be found in Irish writing no less than in Irish speech. However, as I partly suggested at the beginning, this thrawnness of his - and I deliberately do not use a so-called "standard English" term like "perversity," which would have moral implications I am not concerned with here - makes him more rather than less of an Irish novelist. Not for him the witty indirections and verbal cajoleries of a Banville or even the deprecating fastidiousness of a Trevor. His stories are stories of everyday rural experience at an unusual pitch of endurance and tenacity and marked by an unusual capacity for tenderness and lyricism. This, for me at any rate, lifts the lives he records out of the mere bleakness which constantly threatens to engulf them and gives them exemplary status. Out of the customary rhythms of their monotonous courses - ploughing, digging, haymaking, harvesting, pounding the narrow roads of their narrow country, performing endless household chores, and always to the ticking of the clocks devised by nature and by man $\mathbf{M}^{\mathrm{c}}$ Gahern's people learn old and unfashionable lessons of control, patience, reconciliation and solidarity. Though ideals wither and pride is chastised and life seems to be a succession of diminishments, there remain the small consolations of personal courage and loyalty, the larger release of love and pleasure, and, most tellingly, a quite breathtaking openness to the experience of the world's beauty while it lasts.

\section{Notes}

1. John $\mathrm{M}^{\mathrm{c}} \mathrm{Gahern}$, in "L'image," Lignes de fond, quoted by Henri-D. Paratte, "Conflicts in a Changing World: John McGahern," in P. Rafroidi and M. Harmon, eds. The Irish Novel in Our Time (Université de Lille, 1975-6), p. 320.

2. Lorna Sage, in her essay on Flann O'Brien in D. Dunn, ed., Two Decades of Irish Writing (Manchester: Carcanet, 1975).

3. "Hearts of Oak and Bellies of Brass," Nightlines (London: Faber, 1970).

4. J. McGahern, The Barracks (London: Faber, 1963), p. 59.

5. The Dark (London: Faber), p. 122 and p. 160.

6. Roger Garfitt, "Constants in Contemporary Irish Fiction," in D. Dunn, ed., Two Decades of Irish Writing (Manchester: Carcanet, 1975), p. 221.

7. S. Beckett, Proust (New York: Grove Press, 1970), p. 8.

8. In Nightlines.

9. Jonathan Raban, p. 78. 
10. John $\mathbf{M}^{\mathrm{c}}$ Gahern, Preface to the 2nd edition of The Leavetaking (London: Faber, 1984).

11. J. Raban, loc. cit., p. 78.

12. John Cronin, Studies 58: 232 (Winter, 1969), p. 427.

13. F. C. Molloy, "The Novels of John McGahern," Critique, 19 (1977), pp. 5-27.

14. M. J. Toolan, "John M"Gahern: The Historian and the Pornographer," Canadian Journal of Irish Studies, 7 (1981), pp. 39-55.

15. Suzanne J. Fournier, "Structure and Theme in John M'Gahern's The Pornographer," Eire-Ireland, XXII: I (1987), pp. 139-51.

16. R. Garfitt, loc. cit., p. 225.

17. James M. Cahalan, in his The Irish Novel (Dublin: Gill \& Macmillan, 1988) briefly canvasses some possible readings of The Pornographer, esp. p. 275. 